\title{
KŪRYBIŠKUMO SAMPRATA IR JO UGDYMAS DARŽELYJE: IKIMOKYKLINIO AUKLĖJIMO PEDAGOGŲ POZICIJA
}

\author{
Rasa Jautakytè \\ Klaipédos universitetas
}

\begin{abstract}
Anotacija
Straipsnyje pristatoma kūrybiškumo samprata, aptariama jo ugdymo ikimokykliniame amžiuje specifika. Pagrindžiama, kad šiame etape pedagogai vaidina lemiamą vaidmeni organizuojant ị vaiku kūrybiškumo plètrą orientuotą ugdymo procesą. Straipsnyje pristatomas tyrimas, kuriuo siekiama atskleisti ikimokyklinio ugdymo įstaigoje dirbančių pedagogų kūrybiškumo ir jo ugdymo darželyje sampratos ypatumus. Šiam tikslui pasiekti pasirinkta anketinė apklausa, kurioje dalyvavo 174 ikimokyklinio ugdymo pedagogai. Gautiems duomenims apdoroti taikyti turinio analizès, aprašomosios statistikos metodai.

PAGRINDINIAI ŽODŽIAI: kūrybiškumo samprata, kūrybiškumo ugdymas, pedagogai, ikimokyklinis ugdymas.
\end{abstract}

\begin{abstract}
The conception of creativity is introduced and the specifics of development thereof at pre-school age are discussed in the article. It is argued that the pedagogues play a decisive role at this stage when organizing the educational process focused on the development of children's creativity. A research aimed at revealing the peculiarities of the pedagogues', who are employed in a pre-school institution, conception of creativity and development thereof in the kindergarten is presented in the article. A questionnaire survey was chosen in order to achieve this objective; 174 pre-school pedagogues took part in this survey. The content analysis method and the descriptive statistics method were applied in order to process the data obtained.

KEY WORDS: conception of creativity, development of creativity, pedagogues, pre-school education.
\end{abstract}

\section{Ivadas}

XXI amžiuje kūrybiškumas traktuojamas kaip išskirtinis žmogaus gebejjimas, lemiantis jo sẻkmę konkurencingame pasaulyje. Sparčiai kintančios ekonominès sąlygos kelia ypatingus reikalavimus žmogui - iš jo reikalaujama daugiau savarankiškumo, iniciatyvumo, kūrybiškumo. Europos Vadovų Tarybos susitikimo išvadose (2008/C 141/10) dẻl kūrybingumo ir inovacijų skatinimo pasitelkiant švietimą ir mokymą, teigiama: „Keldamos svarbiausią uždavini - užtikrinti pagrindiniu kompetencijų igijimą ir suteikti žinių ir padèti igyti tvirtus būtiniausius gebẻjimus, švietimo ir mokymo sistemos gali atlikti svarbų vaidmenį ugdant kūrybinius ir inovacinius gebejjimus, kaip svarbiausius veiksnius didinant ateityje ekonomini konkurencingumą ir skatinant socialinę sanglaudą ir individualią gerovę; (...) visoje švietimo sistemoje, pradedant mokykla, konkrečios žinios bei gebejjimai turi būti plètojami kartu su bendraisiais gebejjimais, susijusiais su kūrybingumu, tokiais 
kaip smalsumas, intuicija, kritinis bei neverbalinis (kūrybinis) mąstymas, problemų sprendimas, eksperimentavimas, rizikos prisiemimas ir gebejjimas mokytis iš klaidu, vaizduote ir hipotetinis samprotavimas, verslumo pojūtis“ (p. 17).

Dėmesys kūrybiškumo ir iniciatyvumo ugdymui Europoje ir visame pasaulyje inspiravo daugelį švietimo dokumentų, kurie pakoregavo Europos mokyklų programų tikslus. Tačiau kūrybiškumas plètojamas ne tik deklaruojant kūrybiškumo ugdymo siekius švietimo dokumentuose. Kūrybiškumo ugdymo rezultatai priklauso nuo realiu praktinių veiksmų. Pedagogai vaidina lemiamą vaidmenį organizuojant i mokinių kūrybiškumo sklaidą orientuotą ugdymo procesą (Sæbø, 2003; Eckhoff, 2011; Cheung, 2012). Jie ateina į klasę su savo ịsitikinimais ir tai nemažai nulemia jų pasirinkima, ko ir kaip mokyti. Pedagogai tiesiogiai kuria ugdymo procesą, parenka ir planuoja ugdymo turini, numato ugdymo strategiją ir konkrečius uždavinius, derina mokymo metodus bei priemones. Kūrybinè nuostata, stipri kūrybinès veiklos motyvacija pirmiausia turi būti būdinga mokytojo darbui, nes kaip tik jo pozicija nulemia kūrybinę atmosferą mokymo procese (Jonynienè, 2009). Todèl siekiant igyvendinti kūrybiškumo ugdymo siekius, labai svarbu kreipti dèmesi $\mathfrak{i}$ probleminius klausimus: a) kaip pedagogai supranta kūrybiškumą, ir b) koks turètų būti pedagogo realus darbas siekiant užtikrinti kūrybiškumo plètrą (ugdymo strategijos numatymas, palankios aplinkos kūrimas, ugdymo turinio konstravimas, metodų bei mokymo/si būdų pasirinkimas).

Kūrybiškumo sampratos aiškinimą apsunkina požiūriu i kūrybiškumą ịvairovè. Tradiciškai kūrybiškumas apibrěžiamas kaip asmens gebejjimas atrasti tai, kas yra nauja, originalu, netikèta (Sternberg, Lubart, Kaufman, 2005; Runco, 2008; De Bono, 2009). Pastaraisiais dešimtmečiais mokslinèje literatūroje kūrybiškumo fenomenas nagrinètas kaip kūrybos procesas ir jo rezultatas, asmenybès savybe ir mąstymo gebejjimas.

Kūrybiškumas, kaip procesas, apibūdinamas kaip tam tikra kūrybinio mąstymo ịvairovè, estetinis pasaulio suvokimas. Pabrěžiama kūrybinè intuicija, turtinga fantazija, divergentinis mąstymas, ikvejpimas, pasąmonès aktyvumas (Grecov, 2007; De Bono, 2009). E. P. Torrance (1988) nuomone, kūrybiškumas turi būti suprantamas kaip divergentinis mąstymas, pripažistant kūrybinius ieškojimus, kurie lemia netikètus rezultatus. Kūrybinio mąstymo procesą apibūdina gebejjimai: apibrèžti ir iškelti problemą; generuoti keletą idejjų vienu metu; pateikti skirtingų koncepcijų idẻjas; pirmenybę teikti nestandartinėms idèjoms; igyvendinti nestandartines idejas; analizuoti ir sintezuoti informacija, siekiant išspręsti problemą (De Bono, 2009). Divergentinio mąstymo parametrai yra mąstymo sklandumas, lankstumas, originalumas ir detalumas (Torrance, 1988; Petrulytė, 2001; Girdzijauskienè, 2005). 
Kūrybiškumas, kaip asmenybės savybè, - tai atvirumas naujai patirčiai, savarankiškumas, lankstumas, dinamiškumas, originalumas ir kt. Daugelio tyrinètoju (Runco, 2004; Grecov, 2007; Jovaiša, 2007; Girdzijauskienè, 2005; GrakauskaitèKarkockienė, 2006) nuomone, kūrybiškumas yra gebėjimų visuma, kompleksas intelektinių ir asmens savybių, $\mathfrak{i}$ kurị ịeina ir asmens požiūris i gyvenimą. Pažymima, kad kūrybiškumą daugiausia lemia individualios asmenybès savybès: originalumas, lankstumas, sklandumas, smalsumas, jautrumas, energingumas ir savarankiškumas, gebejjimas spręsti problemas ir priimti iššūkius. Kūrybiškumas, kaip rezultatas, - tai gebėjimas sukurti kažką naujo, neiprasto, originalaus; pabrěžiamas naujumas ir socialinis reikšmingumas (Grecov, 2007; Grakauskaitė-Karkockienè, 2006). Kūrybos produktu gali būti laikomi ịvairūs veiklos rezultatai - ir idejjos, ir ìvairių sričių (meno, mokslo, kasdienio gyvenimo) materialūs produktai.

Tokia požiūrių i kūrybiškumą ịvairovė būdinga ir ikimokyklinio ugdymo procesui. Nuo to, kaip pedagogai supranta kūrybiškumą, daug priklauso ir vaikų kūrybiškumo ugdymo ypatumai. Siekiant atpažinti kūrybiškumą ankstyvojo ugdymo aplinkoje, būtina išsami jo samprata (Torrance, 1988; Sharp, 2004; Amabile, 2011), kuria remiantis kiekvienas vaikas yra menininkas plačiaja to žodžio prasme, kiekvienas turi kūrybini potenciala, kuris turi būti lavinamas, daugiau dèmesio skiriant ne procesui, o produktų vertinimo kokybei.

Mokslininkai (Petrulytè, 2001; Grakauskaitè-Karkockiené, 2003; Pilkauskaitè-Valickienè, 2013) skiria tokius kūrybiškumą skatinančius veiksnius: turtingas vaiko patyrimas, vaiko autonomija, savarankiškumas ir laisvo pasirinkimo galimybè, savigarbos skatinimas, vaiko motyvacinès, emocinès ir vertybinès sistemos ugdymas bei kūrybingos asmenybės bruožų formavimas. Ypač pabrēžiama aplinkos ittaka kūrybiškumui (Souza, 2000; Grakauskaitė-Karkockienė, 2006; Beghetto, 2007; Pilkauskaitè-Valickienè, 2013; Girdzijauskienè, 2013). Vaikų kūrybiškumas pasireiškia tik saugioje aplinkoje, kuri pasižymi pagarba ir pasitikejimu, kurioje vaikai yra skatinami, giriama už naujoves. Remiantis kitu tyrejjų (Cropley, 2009; Jeffrey, 2006; Cheung, 2012) įžvalgomis, kūrybiškumą skatina turtinga, ivvairi aplinka, kurioje yra pakankamai priemonių ir laiko. Kūrybiškumą slopina (Souza, 2000; Bražienė, 2004; Grakauskaitè-Karkockienè, 2006; Pilkauskaitè-Valickienė, 2013) neigiama pedagogo reakcija ir kritika, pagarbos trūkumas, apribojimai, perdèta vaiko globa, slopinanti jo savarankiškuma, konservatyvi ir skurdi aplinka, perkrauti ugdymo planai, laiko stoka, dideli lūkesčiai, draugu netolerancija, nepasitikèjimas savimi, baimè, nerimas, psichologinè įtampa.

Pripažįstama, kad vaikų kūrybinę raišką galima skatinti taikant įvairius metodus. Lavinant vaikų kūrybiškumą svarbiausia yra ugdyti kūrybini, kritinį mąstymą (Scott, Leritz, Mumford, 2004; Copple, Bredekamp, 2009; Pilkauskaite-Valickie- 
nè, 2013). Kūrybiškumą skatina galimybès manipuliuoti informacija, piešti piešinius, pasakoti istorijas, issitraukti i vaidybinius žaidimus (Crafts, 2000; Runco, 2006; De Bono, 2009). Vaikų kūrybiškumas ir vaizduotė stimuliuojama klausimais, skatinančiais divergentini mąstymą užduodant atvirojo tipo klausimus, raginant vengti paprastų ir ịprastų atsakymų, modeliuojant kūrybinį mąstymą ir elgesí, skatinant eksperimentuoti, pagiriant vaikus, kurie pateikè netikètus atsakymus (Torrance, 1988; Grakauskaitė-Karkockienè, 2006; De Bono, 2009).

Kūrybiško žmogaus ugdymas nuo pat mažens mokytojams tampa iššūkiu. Mokslininkai vieningai sutaria, kad ikimokyklinis ugdymas vaikui suteikia daugiausia galimybių kūrybiškumo raiškai ir plètotei. H. Gardner (1993) teigimu, kiekvienas vaikas gimsta turẻdamas kūrybini potencialą, o amžius nuo trejų iki penkerių metu yra pats svarbiausias vaiko kūrybiškumo vystymuisi. Vaiko kūrybiškumą lemia ne tik igimtas saviraiškos, bet ir pažinimo poreikiai, skatinantys gilintis į save ir į supantị pasauli. Tai, ką vaikas patiria šiuo raidos periodu, dažnai nulemia visą tolesnę jo asmenybės vystymosi krypti. Todèl labai svarbu pradèti ugdyti vaikų kūrybiškumą nuo pat jo pirmujų žingsnių šeimoje ir ikimokyklinio ugdymo isstaigoje. Svarbiausias vaidmuo ugdymo aplinkoje tenka pedagogui. Nuo jo įsitikinimų, kūrybinių nuostatų, gebejjimo įtraukti vaikus ị kūrybinę veiklą priklauso vaikų kūrybinis aktyvumas ir realūs kūrybos rezultatai. Todèl išsamesné analizè, kaip ikimokyklinio ugdymo pedagogai supranta kūrybiškumą ir koks ju realus darbas su vaikais, padès nustatyti kūrybiškumo ugdymo būdus ikimokyklinio ugdymo įstaigose.

Tyrimo objektas - kūrybiškumo ir jo ugdymo darželyje samprata.

Tyrimo tikslas: atskleisti, kaip ikimokyklinio ugdymo įstaigos pedagogai aiškina kūrybiškumo esmę ir jo ugdymo darželyje ypatumus.

Tyrimo metodai: pedagoginès, psichologinès literatūros analizè, anketinè pedagogų apklausa, kokybinė ir kiekybinė tyrimo duomenų analizė.

\section{Tyrimo metodologija}

Tyrimo imtis. Tyrimas atliktas 2012 metais. Jame dalyvavo ikimokyklinio ugdymo pedagogai iš 24 Klaipedos miesto ir rajono ikimokyklinio ugdymo įstaigų: 19 darželių, 3 mokyklų-darželių, 1 specialiosios mokyklos-darželio, 1 ugdymo centro. Respondentai pasirinkti tikslinès atrankos būdu: tai pedagogai, dalyvavę tarptautinio Comenius projekto „Kūrybiškumo ugdymo ikimokykliniame amžiuje tinklo kūrimas" renginiuose, besidomintys kūrybiškumo ugdymo problematika ir šiuo aspektu siekiantys plètoti savo pedagogines kompetencijas. Iš viso tyrime dalyvavo 174 ikimokyklinių isstaigu pedagogès, turinčios didelę pedagoginę patir- 
tị, pusė visų tyrime dalyvavusių pedagogų turi didesnę nei 20 metų darbo patirtị. Turima pedagoginio darbo patirtis ir dėmesys kūrybiškumo ugdymo problematikai padejo surinkti objektyvią išsamią informaciją, kuri gali padèti išsiaiškinti probleminius tyrimo klausimus.

1 lentelè. Pedagoginè patirtis metais $(\%, \mathrm{sk}$.

\begin{tabular}{|c|c|c|c|c|c|c|c|}
\hline Pedagogine patirtis metais & $1-5$ & $6-10$ & $11-15$ & $16-20$ & $21-25$ & $26-30$ & $31-35$ \\
\hline $\begin{array}{l}\text { Procentai } \\
\text { skaičius }\end{array}$ & $\begin{array}{l}2,9 \\
5\end{array}$ & $\begin{array}{l}11,0 \\
19\end{array}$ & $\begin{array}{l}13,8 \\
24\end{array}$ & $\begin{array}{l}21,2 \\
37\end{array}$ & $\begin{array}{l}30,5 \\
53\end{array}$ & $\begin{array}{l}12,6 \\
22\end{array}$ & $\begin{array}{l}8,0 \\
14\end{array}$ \\
\hline
\end{tabular}

Tyrimo instrumentas. Tyrime naudota tarptautinio Comenius projekto „Kūrybiškumo ugdymo ikimokykliniame amžiuje tinklo kūrimas" anketa pedagogams. Jos struktūra remiasi pagrindiniais šio projekto tikslais ir sudarytu instrumentu (Diakidoy, Kanari, 2012). Anketoje pateikta įvairių klausimų, tačiau šiame straipsnyje apibendrinami tik tie duomenys, kurie padeda atsakyti į išsikeltus klausimus. Analizuojamos dvi klausimų grupès: 1) kūrybiškumo samprata; 2) kūrybiškumo ugdymo patirtis. Siekiant atskleisti pedagogų turimą kūrybiškumo samprata, pateiktas atvirojo tipo klausimas, kviečiantis pasamprotauti apie kūrybiškumą. Pedagogų turimą kūrybiškumo ugdymo patirti padejo išsiaiškinti atvirojo tipo klausimai apie: 1) pedagogų taikomus kūrybiškumo ugdymo būdus bei 2) pedagogų nuomonę apie vaikų kūrybiškumą slopinančias užduotis ir aplinkos charakteristikas. Norint gauti tikslesnès informacijos apie konkrečių ugdymo metodų veiksmingumą ugdant vaikų kūrybiškumą, respondentams pateikta dešimt klausimų ir užduočiu pavyzdžių. Prašyta pažymèti, skatina ar slopina jie vaikų kūrybiškumą.

Gautiems duomenims apdoroti taikytas turinio analizès metodas, duomenys interpretuojami, pedagogų atsakymuose ieškant pasikartojančių nuomonių ir požiūrių. Iliustruojantys teiginiai darbe pateikiami originalia respondentų kalba. Gauti duomenys grupuojami i kategorijas ir subkategorijas, kas leidžia toliau atlikti jų analizę atskleidžiant esmines pedagogų nuomones apie kūrybiškumą ir jo ugdymą. Apibendrinimai pateikiami aprašomosios statistikos metodais. Lentelèse pateikiamas respondentų atsakymu pasiskirstymas procentais ir absoliučiaisiais skaičiais. Procentai skaičiuojami nuo visų tyrime dalyvavusių respondentų skaičiaus. Nuomonių ir respondentų skaičius gali nesutapti, nes vienas respondentas gali pasakyti kelis dalykus.

\section{Tyrimo rezultatai}

Kūrybiškumo samprata. Siekta išsiaiškinti, kaip pedagogai supranta kūrybiškumą ugdymo procese. Respondentai pateikè labai ịvairius atsakymus. Kalbè- 
dami apie kūrybiškumą pedagogai pereina prie kūrybiškumo ugdymo problematikos, kūrybiškumo samprata glaudžiai siejama su ugdymo būdais. Beveik trečdalis respondentų (31 proc.) kūrybiškumą sieja su vaiko gebejimu originaliai mąstyti. Jų nuomone vaikai iš prigimties yra smalsūs, mėgsta bandyti, tyrinèti, eksperimentuoti ir fantazuoti. Todèl pedagogai vaikų kūrybiškumą sieja su jų laisvumu, originalumu, smalsumu; gebėjimu laisvai, vaizdžiai, kūrybiškai, nestandartiškai išspręsti iškilusiq problemq ar priimti, pasiūlyti fantastiškq sprendimo būda; gebéjimu nestandartiškai mastyti, improvizuoti, rasti išeiti bet kokioje situacijoje.

Kita dalis (21,8 proc.) respondentų kūrybiškumą apibrèžia kaip menini gebèjimą. Jie pabrèžia, kad vaikų kūrybiškumas ikimokykliniame amžiuje labiausiai atsiskleidžia meninès veiklos metu, nes kiekvienas vaikas, nepaisant jo meniniu gebejjimų ar patirties, savo raiškos poreikị išreiškia spalvomis, linijomis, muzikos garsais, judesiais ar vaidyba. Dešimtadalis respondentų ( 9,8 proc.) kūrybiškumą supranta kaip vaiko gebejimą sukurti kažką originalaus. Jų nuomone, vaiko kūryba pasižymi drąsa, yra spontaniška, nuoširdi, naivi. Vaiko kūrybiškumą pedagogai dažniausiai sieja su: gebejjimu ir noru atlikti užduoti savaip, netradiciškai, laisvai pasirenkant jam reikalingas priemones; gebėjimu atlikti užduotis jas patiems pasunkinant ar palengvinant pagal savo gebejimus; naudotis platesne nei duota informacija; gebèjimu ne tik ivykdyti pateiktas užduotis, bet ir pačiam „pridèti“ savo veiklas; gebejimu atrasti naujus ir originalius sprendimus, daryti ka nors unikalaus.

Kaip minèta, pristatydami turimą kūrybiškumo sampratą pedagogai išsakẻ pastebejjimus, susijusius su vaikų kūrybiškumo ugdymu. Analizuojant atsakymus pastebima, kad svarbiausiais veiksniais ugdant vaikų kūrybiškumą pedagogai mano esant aktyvią paties pedagogo veiklą ir tinkamos aplinkos grupèje sukūrimą. Pedagogai (27 proc.) suvokia savo vaidmeni ugdant vaikų kūrybiškumą. Vieno pedagogo teigimu, kūrybiškumo ugdymas - tai pedagogo nuostata suteikti vaikui galimybe visapusiškai lavèti, atrasti savo ypatingus gebejjimus reikšti originalias idejas, ieškoti atsakymo ì rūpimus klausimus pasitelkiant vaizduotę, plètoti pažinimo procesus. Pedagogas turi skatinti vaikq kurti, laisvai veikti, nebijoti klysti, išsakyti savo mintis, ieškoti originaliu atsakymu, neprimesti vaikui savo nuomonès. Vaikų saviraiška skatinama suteikiant jiems kūrybinę laisvę, o pedagogas tik nukreipia viską tinkama linkme. Todèl svarbu sudaryti sqlygas vaikams laisvai rinktis veikla, jos atlikimo büdus, pasirinkti priemones savo veiklai igyvendinti, laika. Svarbu kūrybinei veiklai parinkti originalius ir netradicinius būdus bei priemones.

Dalies (10,3 proc.) respondentų nuomone, kūrybiškumui skatinti pirmiausia būtina sukurti tinkamą aplinka, parinkti tinkamas priemones, o tada skatinti vaiku pasitikejjimą savimi kurti, ieškoti, atrasti. Svarbu, kad aplinka atitiktu vaiku amžiaus ypatumus, būtu sudarytos sqlygos savarankiškai vaiku veiklai. Grupès aplin- 
koje turètu netrūkti ịvairiu ir naujovišku priemoniu, kurios visada bütu prieinamos vaikams. Taip pat labai svarbi draugiška ir demokratiška grupès atmosfera.

Apibendrintas pedagogų požiūris ị ikimokyklinio amžiaus vaikų kūrybiškumą pristatytas 2 lenteleje.

2 lentele. Kūrybiškumo samprata

\begin{tabular}{|l|l|l|}
\hline \multicolumn{1}{|c|}{ Kategorija } & \multicolumn{1}{|c|}{ Subkategorija } & \multicolumn{1}{c|}{ Atsakymų skaičius } \\
\hline Kūrybiškumas & $\begin{array}{l}\text { Gebejjimas originaliai mąstyti } \\
\text { Meniniai gebejjimai } \\
\text { Gebejjimas sukurti kažką originalaus }\end{array}$ & $\begin{array}{l}58(21 \%) \\
17(9,8 \%)\end{array}$ \\
\hline Kūrybiškumo ugdymas & $\begin{array}{l}\text { Palankios aplinkos kūrimas } \\
\text { Vaikų saviraiškos skatinimas }\end{array}$ & $\begin{array}{l}18(10,3 \%) \\
47(27 \%)\end{array}$ \\
\hline
\end{tabular}

Kūrybiškumo ugdymo būdų pavyzdžiai. Išanalizavus pedagogų atsakymus paaiškejjo, kad jie taiko gana daug ivvairių būdų, skatinančių vaikų kūrybiškumą. Siekdami iraukti vaikus į meninę veiklą, pedagogai (taip nurodė 44,8 proc. respondentu) pateikia ịvairiu kūrybinių užduočių: vaikams pateikiamas nedidelis fragmentas, o vèlesnis rezultatas priklauso nuo jo vaizduotès, kūrybiškumo; duodami nebaigti piešiniai, kuriuos vaikai patys turi užbaigti; tapyti klausantis muzikos. Vaikai skatinami kurti pasakas, missles, trumpus eilèraštukus, pasakojimus. Vaikų kalbinei raiškai plètoti pedagogès rengia logines, kalbines klausimų ir atsakymu popietes, diskusinius pokalbius, savęs pristatymo minutes ir kt.

Svarbia veikla, ugdant vaikų kūrybiškumą, pedagogai mano esant projektinę veiklą, kuri glaudžiai susijusi su menine veikla (tokią nuomonę išsakẻ 23 proc. tiriamuju). Tai meninės projektinès savaitės, kalendorinių švenčių renginiai, atvirų durų dienos, bendros šventės kartu su tėveliais, konkursai, išvykos, ekskursijos.

Vaikų kūrybiškumui ugdyti, pedagogų ( 21,3 proc.) nuomone, labai svarbi žaidybinè veikla. Todẻl dažnai žaidžiami kūrybiniai, siužetiniai žaidimai, kurių iniciatoriai būna patys vaikai. Vaikai lengvai ịsitraukia į žaidimus, kuriuos kuria ne auklètoja, o patys vaikai; geba savarankiškai kurti ir vystyti siužetiní žaidima; ...žaidimo metu naudoti ne tik žaislus, bet ir pačias j̇vairiausias priemones, aplinkoje esančius tinkamus daiktus.

Siekị kurti ypač skatina pakankamas įvairių medžiagų ir priemonių kiekis grupèje (todèl pedagogai [16,7 proc.] stengiasi turèti grupeje kuo įvairesnių priemoniu veiklai pagal vaikų individualius poreikius ir interesus) bei netradicinès užduotys: kūrybiniams darbams suteikiama laisvè rinktis priemones, atlikimo technika; meniniai darbai atliekami naudojant inovatyvias priemones - magnetines lentutes, modelina, spalvota smèli; piešiama vandenyje spalvotu vandeniu, šlapia plunksna ant 
šaligatvio. Noredami pristatyti vaikų kūrybinès veiklos rezultatus, pedagogai (11,5 proc.) organizuoja vaikų darbų parodas įstaigoje ir už jos ribų (eksponuojami vaiku darbeliai, kad jais pasidžiangtu visi ir tuo skatintu vaikus dar labiau stengtis).

Vaikai itraukiami į aplinkos stebejjimą, tyrinèjimą, eksperimentus (12 proc.): vaikai tyrinejja tai, kas aplink - isižiūri, issiklauso, uodžia, ragauja, liečia, stebi atsiradima, pokyčius - ilgesni laika kryptingai stebi ¿̨domesnius reiškinius, kq nors trumpai stebi kasdien; tyrinejja techninius atradimus - magneto trauka, mikroskopo galimybes, teleskopo; vaikai stebi, klausineja, ieško informacijos knygose, samprotauja, tyrineja, eksperimentuoja; žinias arba patirtí bando pritaikyti naujame kontekste. Dažnai tokie eksperimentai vyksta lauke, tyrinejjant gamtinę medžiaga, garsus, daiktus.

Dalis respondentų (11,5 proc.) vaikų kūrybiškumą siekia ugdyti lavindami jų mąstymą - užduodami atviruosius klausimus, kurie skatina tolesnius tyrinëjimus ir apmąstymus, klausimus, kurie turi keletą atsakymų: neskubame vaikui duoti atsakyma, užduodame jam tokius klausimus, kurie padeda pačiam rasti atsakyma, pvz. „,Kas būtu, jei ... “. Vaikai skatinami dalyvauti loginèse pratybose, itraukiami i problemų sprendimą, skatinami originaliai atsakyti i problemini klausima, nekartoti kitu, pateikti savo sumanyma sugalvoti nežinomo daikto panaudojimo galimybes.

Dideli dèmesi pedagogai (37,4 proc.) skiria saugios, vaikų kūrybiškumą stimuliuojančios aplinkos kūrimui. Jie pabrèžia, kad aplinka turi būti nuotaikinga, žaisminga, spalvinga ir saugi. Siekiama, kad kuriama erdve tenkintu ivairius vaiku interesus ir skatintu norq tyrineti. Tokioje aplinkoje vaikas turi galimybę laisvai fantazuoti, reikšti mintis, idejjas ir jas išreikšti kūryboje.

Ugdant vaikų kūrybiškumą svarbi bendra vaiko ir pedagogo veikla (tokią nuomonę išsakè 26,4 proc. respondentu), kai su vaiku bendraujama ir bendradarbiaujama kaip su sau lygiu, kai vaikas paremiamas, iškilus nesèkmei, jam padedama kai jis to prašo ar laukia pagalbos, pasiūloma nauju ideju, sumanymu tyrinejjimui ir veiklai, taip skatinant vaiko pasitikëjimq savimi, žadinant kūrybinę saviraiška. Respondentai pažymi, kad vaikai ir pedagogai yra lygiaverčiai veiklos dalyviai, todẻl organizuoja veiklą grupeje, atsižvelgiant ị vaikų pasiūlymus ir pageidavimus. Stengiuosi sudaryti sqlygas vaikui rinktis veikla, jos atlikimo būdus, priemones, laika; svarbus yra vaiku stebejimas, kiekvieno vaiko poreikiu tenkinimas. Vaiku kūrybiškumą skatina pagyrimai ir paskatinimai ne tik už atliktą darbą, išspręstą užduotị, bet ir už pastangas. Dalis pedagogu pabrèžè, kad svarbu i darželio veiklą itraukti ir tèvus, todèl rengiamos atvirų durų dienos, kurių metu ne tik tėvai, bet ir kiti pedagogai gali apsilankyti ir pasidalinti savo geraja patirtimi, rengia šventes kartu su tèveliais, bendras vaikų ir tėvų kūrybinių darbų parodas, skatina kartu su vaikais dalyvauti meninès raiškos konkursuose. Apibendrinti pedagogų atsakymai pateikiami 3 lenteleje. 
3 lentelè. Pedagogų nurodyti būdai, skatinantys vaikų kūrybiškumą

\begin{tabular}{|l|l|l|}
\hline \multicolumn{1}{|c|}{ Kategorija } & \multicolumn{1}{c|}{ Subkategorija } & \multicolumn{1}{c|}{ Atsakymų skaičius } \\
\hline \multirow{4}{*}{$\begin{array}{l}\text { Kūrybiškumo } \\
\text { ugdymo būdai }\end{array}$} & Meninės veiklos užduotys & $78(44,8 \%)$ \\
\cline { 2 - 3 } & Projektinè veikla & $40(23 \%)$ \\
\cline { 2 - 3 } & Žaidybinè veikla & $36(21,3 \%)$ \\
\cline { 2 - 3 } & Netradicinès medžiagos ir užduotys & $29(16,7 \%)$ \\
\cline { 2 - 3 } & Eksperimentavimas, tyrinèjimas & $21(12 \%)$ \\
\cline { 2 - 3 } & Probleminiai klausimai ir užduotys & $20(11,5 \%)$ \\
\cline { 2 - 3 } & Kūrybinių darbu parodos & $20(11,5 \%)$ \\
\hline \multirow{4}{*}{$\begin{array}{l}\text { Kūrybiškumui } \\
\text { palankios aplinkos } \\
\text { kūrimo būdai }\end{array}$} & Kūrybiškos aplinkos kūrimas & $65(37,4 \%)$ \\
\cline { 2 - 3 } & Pedagogo ir vaiko sąveika & $46(26,4 \%)$ \\
\hline
\end{tabular}

Kūrybiškumą slopinančios užduotys ir aplinkos charakteristikos. Apibendrinus pedagogų nuomones apie tai, kas slopina vaikų kūrybiškumą, pedagogų atsakymai suskirstyti ị dvi kategorijas: kūrybiškumą slopinančios užduotys ir kūrybiškumui nepalanki aplinka. Kaip vieną iš kūrybiškumą slopinančių užduočiu pedagogai (25,3 proc.) pažymėjo nurodymus, kaip tiksliai atlikti užduotis ar veiklą. Vaikų kūrybiškumą slopina , akademinis mokymas piešti pagal pavyzdi, standartiniu užduočiu atlikimas; kai rodome vaikui, kaip piešiamas vienas ar kitas daiktas; duodamas konkretus pavyzdys, vaikas ji kopijuoja, kai nurodoma daryti taip ir ne kitaip; labai smulkus, detalus, nukreipiantis i tam tikrus rèmus užduoties išaiškinimas.

Kūrybiškumą slopina spalvinimas knygučiu ir piešimas pagal šablona, nes vaikai nebesiekia kažka kurti, o tiesiog piešia ir spalvina; piešimas pagal pavyzdi, trafaretu spalvinimas ir apipiešimas. Respondentai (12,3 proc.) pabrèžia, kad vaiko galimybių nepaisymas taip pat slopina vaiko kūrybiškumą: ,keliami vienodi reikalavimai neatsižvelgiant $\dot{k}$ vaiko galimybes; kai padaroma, sugalvojama, pasakoma už vaika, neitraukiant vaiko, nę̇vertinant vaiko galimybiu, gebėjimu; jei veikla atliekama iš karto su visais vaikais ir užduotis yra vienoda visiems vaikams ir rezultatas turi büti vienas. Respondentai ( 9,8 proc.) atkreipé dèmesi, kad neigiamai vaikus veikia pedagogų siekis gauti norimą rezultatą: rezultato siekimo iškèlimas aukščiau už proceso vyksma. Ypač pabrěžiamas pedagogų noras pasiekti labai geru, gražiu rezultatu meninejje veikloje, kategoriškai nurodant vaikui, ka jis turi padaryti, bei neleidžiant vaikui pačiam spręsti. Neigiamai veikia įvairūs renginiai ir net parodomosios, atviros veiklos, kai vaikas tiesiogiai vykdo ir atlieka užduotis, paskirtas pedagogo. Tai lemia siekimas teigiamo rezultato.

Rimtas kūrybiškumo ugdymo kliuvinys, pasak pedagogų, yra nepalanki aplinka. Ypač neigiamai vaikų kūrybiškumą veikia perdetas vadovavimas vaikų veiklai (taip teigia 26,4 proc. respondentų), kai pedagogas aktyviai issiterpia ị vaiko kūry- 
binius žaidimus, nurodinèja, kq ir kaip daryti. Kūrybiškumą slopina pasirinkimo laisvès apribojimas, kai vaikui yra draudžiama savarankiškai pasirinkti veikla, priemones, reikalaujama veikti pagal pedagogo nurodytas taisykles, ignoruojama jo iniciatyva; suaugusiojo reikalavimai vienaip ar kitaip atlikti užduotis. Ypač mokymas piešti, ar kategoriški reikalavimai inscenizuojant, žaidžiant. Kaip kitas kūrybiškumą slopinančias priežastis respondentai (22,4 proc.) nurodo laiko stoka, kai vienas renginys keičia kita; vaikams pateikiami labai dideli informacijos krūviai, todèl vaikai mokomi skubant, draudimus vaikams pasirinkti žaidimus, veiklos priemones ir vaiko iniciatyvos slopinimą (tokią nuomonę išsakè 19,5 proc. respondentų). Vaikų kūrybiškumą slopina skurdi daiktinè-žaidybinė ugdomoji grupès aplinka, nepakankama erdvė grupèje, nes vaikas negali laisvai, netrukdomai domètis ir pažinti aplinkq, bendrauti su bendraamžiais, suaugusiais, naudotis visomis grupejje, istaigoje esančiomis priemonèmis. Per didelè vaiko globa taip pat slopina vaikų kūrybiškumą (taip teigia 6,9 proc. respondentų). Pernelyg globojamas vaikas nebesugeba savarankiškai pasirinkti ir veikti, nes ipranta, kai už ji viskas yra padaroma (vaikas sako - aš nemoku), taip pat nesėkmès baimė (4 proc. respondentu): ,pastebejjau, kad labai tikslus veiksmu ir emociju nurodymas trukdo vaiko išraiškai, jis bijo suklysti ir galiausiai arba atsisako vaidmens arba pravirksta. Pedagogų pateikti kūrybiškumą slopinančių užduočių ir aplinkos charakteristikos pavyzdžiai pateikti 4 lentelèje.

4 lentelè. Kūrybiškumą slopinančios užduotys ir aplinkos charakteristikos

\begin{tabular}{|l|l|l|}
\hline \multicolumn{1}{|c|}{ Kategorija } & \multicolumn{1}{|c|}{ Subkategorija } & \multicolumn{1}{|c|}{ Atsakymų skaičius } \\
\hline \multirow{2}{*}{$\begin{array}{l}\text { Kūrybiškumą } \\
\text { slopinančios } \\
\text { užduotys }\end{array}$} & Tikslūs darbų pavyzdžiai, veiklos modeliai & $44(25,3 \%)$ \\
\cline { 2 - 3 } & $\begin{array}{l}\text { Iš anksto paruošti trafaretai, šablonai, knygelių } \\
\text { spalvinimas }\end{array}$ & $40(23 \%)$ \\
\cline { 2 - 3 } & Vaiko galimybių nepaisymas & $22(12,3 \%)$ \\
\cline { 2 - 3 } & Rezultato siekis & $17(9,8 \%)$ \\
\hline \multirow{4}{*}{$\begin{array}{l}\text { Kūrybiškumui } \\
\text { nepalanki aplinka }\end{array}$} & Perdètas vadovavimas (autoritarinis) & $46(26,4 \%)$ \\
\cline { 2 - 3 } & Skubotumas, kantrybės stoka & $39(22,4 \%)$ \\
\cline { 2 - 3 } & Draudimai, vaiko iniciatyvos slopinimas & $38(21,8 \%)$ \\
\cline { 2 - 3 } & Skurdi aplinka & $13(7,5 \%)$ \\
\cline { 2 - 3 } & Perdèta vaiko globa & $12(6,9 \%)$ \\
\cline { 2 - 3 } & Vaiko nesėkmės baimė & $7(4 \%)$ \\
\hline
\end{tabular}

Pedagogu nuomonè apie užduotis, skatinančias ir slopinančias vaikų kūrybiškumą. Daugiausia respondentų prie labiausiai vaikų kūrybiškumą skatinančiu užduočiu priskyrè klausimus ir užduotis, kurie yra neapibrèžti (nėra tikslūs, verčia pamąstyti), turi kelis teisingus atsakymus, atvirojo tipo klausimai 
bei klausimai ir užduotys, ị kuriuos atsakyti / išspręsti auklètiniai turi nedaug arba visai neturi susijusių žinių, taip pat klausimai ir problemos, kurie auklètiniams nepažistami.

Daugiausia respondentų prie labiausiai vaikų kūrybiškumą slopinančiu užduočių priskyrè klausimus ir užduotis, kurie turi aiškiai numatomą atsakymą / sprendimo būdą. Be to, respondentų nuomone, labiau vaikų kūrybiškumą slopina klausimai ir užduotys, kurios turi vieną teisingą atsakymą / sprendimo būdą, bei uždarojo tipo klausimai, turintys numatomą atsakymą. Apibendrinti pedagogų atsakymai pateikti 5 lentelèje.

5 lentelè. Klausimai ir užduotys, labiau skatinančios ar slopinančios vaiku kūrybiškumą

\begin{tabular}{|c|c|c|c|}
\hline $\begin{array}{l}\text { Užduotys, skatinančios ar slopinančios vaiku } \\
\text { kūrybiškumą }\end{array}$ & Slopina & Skatina & Neatsakè \\
\hline Atvirojo tipo klausimai & $24(13,7 \%)$ & $\begin{array}{l}139 \\
(80 \%)\end{array}$ & $11(6,3 \%)$ \\
\hline Uždarojo tipo klausimai & $\begin{array}{l}\mathbf{1 4 0} \\
(80,4 \%)\end{array}$ & $\begin{array}{l}26 \\
(15 \%)\end{array}$ & $\begin{array}{l}8 \\
(4,6 \%)\end{array}$ \\
\hline $\begin{array}{l}\text { Klausimai / užduotys, kurios turi vieną teisingą } \\
\text { atsakymą / sprendimo būdą }\end{array}$ & $\begin{array}{l}146 \\
(84 \%)\end{array}$ & $\begin{array}{l}18 \\
(10,3 \%)\end{array}$ & $\begin{array}{l}10 \\
(5,7 \%)\end{array}$ \\
\hline $\begin{array}{l}\text { Klausimai ir užduotys, kurios turi kelis } \\
\text { atsakymus / sprendimo būdus }\end{array}$ & $\begin{array}{l}6 \\
(3,4 \%)\end{array}$ & $\begin{array}{l}\mathbf{1 6 4} \\
(94,3 \%)\end{array}$ & $\begin{array}{l}4 \\
(2,3 \%)\end{array}$ \\
\hline $\begin{array}{l}\text { Klausimai ir užduotys, kurios turi aiškiai } \\
\text { numatomą atsakymą / sprendimo būdą }\end{array}$ & 162 & $\begin{array}{l}8 \\
(4,6 \%)\end{array}$ & $\begin{array}{l}4 \\
(2,3 \%)\end{array}$ \\
\hline $\begin{array}{l}\text { Klausimai ir užduotys, kurie nèra tikslūs, verčia } \\
\text { pamąstyti }\end{array}$ & 0 & $\begin{array}{l}\mathbf{1 7 4} \\
(100 \%)\end{array}$ & 0 \\
\hline $\begin{array}{l}\text { Klausimai ir užduotys, kurie auklètiniams } \\
\text { nepažistami }\end{array}$ & $\begin{array}{l}40 \\
(23 \%)\end{array}$ & $\begin{array}{l}\mathbf{1 2 6} \\
(72,4 \%)\end{array}$ & $\begin{array}{l}8 \\
(4,6 \%)\end{array}$ \\
\hline $\begin{array}{l}\text { Klausimai ir užduotys, su kuriais auklètiniai buvo } \\
\text { jau anksčiau susidūrę }\end{array}$ & $\begin{array}{l}56 \\
(32,2 \%)\end{array}$ & $\begin{array}{l}112 \\
(64,4 \%)\end{array}$ & $\begin{array}{l}6 \\
(3,4 \%)\end{array}$ \\
\hline $\begin{array}{l}\text { Klausimai ir užduotys, i kuriuos atsakyti / išspręsti } \\
\text { auklètiniai turi turèti išankstiniu žinių }\end{array}$ & $\begin{array}{l}35 \\
(20,1 \%)\end{array}$ & $\begin{array}{l}\mathbf{1 3 4} \\
(77 \%)\end{array}$ & $\begin{array}{l}5 \\
(2,9 \%)\end{array}$ \\
\hline $\begin{array}{l}\text { Klausimai ir užduotys, i kuriuos atsakyti / išspresti } \\
\text { auklètiniai turi nedaug arba iš viso neturi susijusiu } \\
\text { žinių }\end{array}$ & $\begin{array}{l}64 \\
(36,8 \%)\end{array}$ & $\begin{array}{l}107 \\
(61,5 \%)\end{array}$ & $\begin{array}{l}3 \\
(1,7 \%)\end{array}$ \\
\hline
\end{tabular}

\section{Išvados}

Apibūdindami kūrybiškumą, pedagogai išskiria esminę kūrybiškos asmenybės savybę - originalumą. Kūrybiškumas apibūdinamas ir kaip meninis gebèjimas bei netradicinis kūrybos rezultatas. Pedagogai kūrybiškumo sampratą glaudžiai sieja 
su jo ugdymo būdais ir pabrěžia, kad ikimokyklinio amžiaus vaikų kūrybiškumas, nepaisant jų meninių gabumų ar patirties, labiausiai atsiskleidžia per meninę veiklą. Svarbiausiais veiksniais ugdant vaikų kūrybiškumą pedagogai mano esant aktyvią ir kūrybišką paties pedagogo veiklą, vaikų kūrybišką saviraišką skatinančią bei kūrybiškumo raiškai palankią aplinką grupejje.

Analizuojant pedagogų praktinio darbo ugdant vaikų kūrybiškumą pavyzdžius nustatyta, kad respondentai taiko ịvairius kūrybiškumą skatinančius būdus. Vaikų kūrybiškumo ugdymas ikimokyklinèse įstaigose daugiausia siejamas su menine veikla, ¿̨vairiais meniniais renginiais ir projektais, kūrybinių darbų parodomis, žaidybine veikla. Skatinant vaikų kūrybinį mąstymą vykdomi ịvairūs eksperimentai, aplinkos reiškinių ir daiktų tyrinejjimai, naudojamos netradicinès medžiagos ir užduotys, pateikiami probleminiai klausimai, kurie skatina apmąstymus, kelia naujus klausimus. Kurdami kūrybiškumui palankią aplinką pedagogai siekia, kad ji būtu turtinga, nuotaikinga, tenkinanti vaikų interesus, emociškai saugi. Pedagogų ir vaikų santykiai grindžiami pagarba ir pasitikejimu.

Pedagogų nuomone, labiausiai vaikų kūrybiškumą skatina atviri, neturintys atsakymo variantų klausimai bei užduotys, kurios turi keletą sprendimo variantų ir sudaro vaikams pasirinkimo galimybę. Tuo tarpu labiausiai vaikų kūrybiškumą slopina užduotys, turinčios tik vieną sprendimo variantą, susijusios su formaliu atlikimu - kopijavimu, spalvinimu. Neigiamai vaikus veikia įvairūs draudimai, kritika, reikalavimas veikti pagal pedagogo nurodytas taisykles, laiko stoka, pedagogų noras pasiekti gražių rezultatų.

Gauta 20131002

Pasirašyta spaudai 20140214

\section{Literatūra}

Amabile, T. M., Kramer, S. J. (2011). The Progress Principle: Using Small Wins to Ignite Joy, Engagement, and Creativity at Work. Harvard Business Review Press.

Aljughaiman, A., Mowrer-Reynolds, E. (2005). Teachers' conceptions of creativity and creative students. Journal of Creative Behavior, vol. 39: 17-34.

Beghetto, R. A. (2007). Ideational code-switching: Walking the talk about supporting student creativity in the classroom. Roeper Review, vol. 29, no. 4: 265-270.

Bražienè, N. (2004). Pradiniu klasiu mokiniu kūrybingumo ugdymas pasakomis. Daktaro disertacija. Šiauliai.

Cheung, R. H. P. (2012). Teaching for creativity: examining the beliefs of early childhood teachers and their influence on teaching practices. Australasian Journal of Early Childhood, vol. 37: 43-51.

Copple, C., Bredekamp, S. (2009). Developmentally appropriate practice in early childhood programs serving children from birth through age 8. Washington, DC: National Association for the education of young children. 


\section{KŪRYBIŠKUMO SAMPRATA IR JO UGDYMAS DARŽELYJE: IKIMOKYKLINIO ...}

Craft, A. (2005). Creativity in schools: Tensions and dilemas. Routledge, UK.

Cropley, A. (2009). Creativity in education and learning - a guide for teachers and educators. New York: Routledge Falmer.

De Bono, E. (2009). Lateral Thinking: a textbook of creativity. London: Penguin Books Ltd.

Diakidoy, I., Kanari, E. (1999). Student teacher beliefs about creativity. British Educational Research Journal, vol. 25: 225-243.

Eckhoff, A. (2011). Creativity in the Early Childhood Classroom: Perspectives of Preservice Teachers. Journal of Early Childhood Teacher Education, p. 240-255.

Egan, K. (2005). An imaginative approach to teaching. San Francisco, CA: Jossey-Bass.

Fleer, M. (2012). Imagination, emotions and scientific thinking: what matters in the being and becoming of a teacher of elementary science? Cultural Studies of Science Education, vol. 7, issue 1: 31-39.

Gardner, H. (1990). Art Education and Human Development. California, Los Angeles: Getty Publications.

Girdzijauskienė, R. (2012). Kūrybiškumui ugdyti palanki aplinka Lietuvos mokyklose. Tiltai, nr. 4: 79-89.

Girdzijauskiené, R. ir kt. (2013). Mokiniu kürybiškumo ugdymo gimtosios kalbos pamokose metodika. Vilnius: SMM leidykla.

Girdzijauskienė, R. (2005). Muzikos pedagogu požiūrio į mokinių kūrybiškumo raišką per muzikinę veiklą ypatumai. Pedagogika, nr. 78: 36-42.

Grakauskaitė-Karkockienè, D. (2006). Kürybos psichologijos pagrindai. Vilnius: Logotipas.

Jeffrey, B., Craft, A. (2004). Teaching creatively and teaching for creativity: distinctions and relationships. Educational Studies, vol. 30 (1): 77-87.

Jonynienè, V. (2009). Kūrybinio mąstymo ugdymas pradinėje mokykloje. Žvirbliu takas, nr. 1: 21-29.

Jovaiša, L. (2007). Enciklopedinis edukologijos žodynas. Vilnius: Gimtasis žodis.

Official Journal of the European Union (Ed.) (2008). Conclusions of the Council and of the Representatives of the Governments of the Member States, meeting within the Council of 22 May 2008 on promoting creativity and innovation through education and training (2008/C 141/10).

Petrulytè, A. (2001). Kūrybiškumo ugdymas mokant. Vilnius: Presvika.

Pilkauskaitè-Valickienè, R. (2013). Kas trukdo ugdyti vaiko kūrybingumą ir kaip ugdyti kūrybingas individualybes? Žvirbliu takas, nr. 4: 11.

Pugnaghi, A. (2013). Teachers' implicit theories of creativity. Creativity in Pre-school Education. Sern.

Runco, M. A., Johnson, D. J. (2002). Parents' and teachers' implicit theories of children's creativity: a cross-cultural perspective. Creativity Research Journal, nr. 14: 427-438.

Runco, M. A. (2008). Creativity and education. New Horizons in Education, vol. 56: 96-104.

Runco, M. A. (2006). B. Spodek, O. Saracho (eds.). The development of children's creativity. Handbook of research on the education of young children. Mahwah, NJ: Erlbaum, p. 121-129.

Sæbø, A. B. (2006). Exploring Teaching Creativity and Creative Teaching: the first step in an International Research Project.

Sharp, C. (2004). Developing young children's creativity: What can learn from research? Topic, vol. 32: 5-12.

Sternberg, R. J., Lubart, T. I., Kaufman, J. C., Pretz, J. E. (2005). Creativity. The Cambridge handbook of thinking and reasoning. New York: Cambridge University Press.

Sousa Fleith, D. (2000). Teacher and Student Perceptions of Creativity in the Classroom Environment. Roeper Review, vol. 22: 148-153.

Torrance, E. P. (1988). The nature of creativity as manifest in its testing. Cambridge: University Press.

Грецов, А. Г. (2007). Тренинг креативности для старшеклассников и студентов. СПб.: Питер. 
Rasa Jautakytè

\title{
THE CONCEPT AND DEVELOPMENT OF CREATIVITY IN THE KINDERGARTEN: THE POSITION OF PRE-SCHOOL PEDAGOGUES
}

\author{
Rasa Jautakytė
}

Summary

Creativity is considered to be an exceptional personal skill determining one's success in the competitive world in the $21^{\text {st }}$ century. The rapidly-changing economic conditions are setting special requirements for a person: one needs more independence, initiative and creativity. The focus on the development of creativity and initiative has inspired many educational documents in Europe and worldwide which have adjusted the objectives of the curricula of the European schools. The pedagogues play a decisive role when organizing the educational process focused on the spread of students' creativity. The teacher's work must be, first of all, characterized by the creative attitude and strong motivation for creative activities, as it is the teacher's position that determines creative atmosphere in the teaching process. Therefore, it is very important to pay attention at problematic issues in order to implement the aims of the development of creativity: a) how do the pedagogues understand creativity, and b) what should the pedagogue's actual work be in order to ensure the development of creativity?

The search for the conception of creativity is impeded by the variety of the attitudes towards creativity. Traditionally, creativity is defined as a person's ability to discover something new, original or unexpected. The phenomenon of creativity has been analyzed as the process and result of the creativity, a personal quality and a thinking skill during the most recent decades. Such variety of the attitudes towards creativity is typical to the pre-school education process as well. The peculiarities of the development of children's creativity highly depend on the way the pedagogues perceive creativity as well. In order to recognize creativity in the early education environment, it is necessary to have a broad and democratic conception thereof in accordance with which each child is an artist in the broad sense and everyone has creative potential which must be developed by focusing more on the process and less on the assessment of the quality of the products.

Scholars distinguish the following factors stimulating creativity: child's rich experience, child's autonomy, independence and the possibility to choose freely, encouragement of self-esteem, development of the child's motivational, emotional and value system as well as formation of the characteristics of a creative personality. The influence of the environment on creativity is especially highlighted. 
Children's creativity is evidenced in a safe environment only; such an environment is characterized by respect and trust, children are encouraged and innovations are praised in it. According to other researcher's insights, creativity is stimulated by a rich and variegated environment containing enough means and time. Creativity is suppressed by the pedagogue's negative reaction and criticism, excessive care of the child which suppresses their independence, conservative and poor environment, overloaded educational plans, lack of time, high expectations, friends' intolerance, no self-confidence, fear, anxiety and psychological tension.

It is recognized that children's creative expression may be stimulated by various methods and ways. The most important thing when developing children's creativity is to develop creative and critical thinking. Creativity is stimulated by the opportunities to manipulate information, draw pictures, tell stories and get involved in role plays. Children's creativity and imagination are stimulated by questions encouraging divergent thinking by asking open questions, encouraging children to avoid simple and ordinary answers, modeling creative thinking and behavior, encouraging experiments and praising the children who give unexpected answers.

Scholars unanimously agree that pre-school education gives the most opportunities for the expression and development of creativity to the child. According to $\mathrm{H}$. Gardner, each child is born with creative potential and the age from five to six years is the most important for the development of the child's creativity. Therefore, it is very important to start the development of children's creativity from their very first steps in the family and in the pre-school institution. The most important role in the developmental environment is that of the pedagogue. Children's creative activity and actual results of creativity depend on the pedagogue's convictions, creative attitudes and ability to involve children in creative activities. Therefore, a deeper analysis of the way pre-school pedagogues understand creativity and of their actual work with children will help find out the ways of the development of creativity in pre-school institutions better.

The object of the research is the conception of creativity and development thereof in the kindergarten. The objective of the research is to reveal the way the pedagogues of the pre-school institution explain the essence of creativity and the peculiarities of the development thereof in the kindergarten. The methods of the research: analysis of pedagogical and psychological literature, questionnaire survey of the pedagogues, qualitative and quantitative analysis of the data of the research.

The pre-school pedagogues from 24 pre-school institutions of Klaipeda City and District - 19 kindergartens, 3 schools-kindergartens, 1 special school-kindergarten and 1 education centre - took part in the research. A total of 174 women pre-school pedagogues having a lot of pedagogical experience took part in the research; the employment experience of half of all pedagogues who took part in 
the research is over 20 years. The experience in pedagogical work and attention to the issues of the development of creativity helped obtain objective and thorough information necessary in order to answer the problematic questions of the research.

The questionnaire for the pedagogues of the international Comenius project "Creating a network for the development of creativity at pre-school age" was used in the research. Various questions were presented in the questionnaire; however, only the data which helps answer the questions asked is generalized in this article. Two groups of the questions are analyzed: 1) the conception of creativity, 2) the experience in the development of creativity. In order to reveal the pedagogues' conception of creativity, an open question inviting to express deeper reasoning about creativity was presented. Open questions regarding the following helped find out the pedagogues' experience in the development of creativity: 1) the ways to develop creativity applied by the pedagogues, and 2) the pedagogues' opinion about the tasks and characteristics of the environment which suppress children's creativity.

When describing creativity, the pedagogues distinguish an essential characteristic of a creative personality: originality. Creativity is also described as an artistic skill and an unorthodox result of creation. The pedagogues closely associate the conception of creativity with the ways of the development thereof and emphasize that pre-school children's creativity is revealed during artistic activities the most irrespective of their artistic abilities and experience. The pedagogues consider active and creative activities of the pedagogues themselves as well as the environment stimulating children's creative self-expression and favourable to the expression of creativity in the classroom to be the most important factors when developing children's creativity.

When analyzing the examples of the pedagogues' practical work in the development of children's creativity, it was determined that the respondents use various methods stimulating creativity. The development of children's creativity in preschool institutions is mostly associated with artistic activities. The pedagogues believe that project activities which are closely related to artistic events are important activities in the development of children's creativity. Those events are artistic project weeks, the events of calendar festivals, open door days, joint festivals together with parents, competitions, field trips and excursions. In the opinion of the pedagogues, playful activities are very important for the development of children's creativity.

Various experiments, exploration of environmental phenomena and objects are performed, unorthodox materials and tasks are used and problematic questions which encourage reflections and raise new questions are asked in order to stimulate children's creative thinking. When creating an environment favourable to creati- 
vity, the pedagogues aim for it to be rich, convivial, satisfying children's interests and emotionally safe. The relationships between the pedagogues and the children are based on respect and trust; the activities in the classroom are organized taking into account the children's suggestions and wishes. Children's creativity is stimulated by praise and incentives given not only for the work done or the task solved but also for the efforts.

In the opinion of the pedagogues, open questions without the variants of the answers and open tasks with several variants of the solution which provide the opportunity to choose for the children stimulate children's creativity the most. On the other hand, tasks with only one variant of the solution related to formal performance - copying, colouring, acting in accordance with precise rules - suppress children's creativity the most. Various prohibitions, criticism, disregard of the child's potential and suppression of initiative affect children in a negative manner. The child's creativity is suppressed by the pedagogues' aim to obtain the nice desired result, lack of time and poor material-playful educational environment of the classroom as well. 
